\title{
On the occurrence of Achnanthes thermalis var. rumrichorum (Bacillariophyceae) in Slovakia
}

\author{
Alica HindáKovÁ \\ Institute of Botany SAS, Dúbravská cesta 14, SK-84523 Bratislava, Slovakia; e-mail: alica.hindakova@savba.sk
}

\begin{abstract}
The cell morphology of Achnanthes thermalis var. rumrichorum Lange-Bertalot, a first record for the territory of Slovakia and in Europe, was studied under LM and SEM and documented by micrographs. This diatom was found in the benthos of a gravel-pit lake in Bratislava and in artificial thermal basins in the health-resort park of Piešt'any, Western Slovakia. A discussion of the morphological features of this taxon and their taxonomic affinities with related species is presented.
\end{abstract}

Key words: Bacillariophyceae, Achnanthes, Achnanthidium, Planothidium, phytobenthos, Slovakia

\section{Introduction}

The species Achnanthes thermalis (RABENHORST) SCHÖNFELD was described from a thermal spring in Germany as Achnanthidium thermale RABENHORST 1864, and later found also in other thermal habitats in Europe. Another variety of $A$. thermalis, var. rumrichorum, was established by LANGE-BERTALOT (LAnge-Bertalot \& Krammer 1989) from the Quitobaquito creek in Arizona, USA.

In the last years, populations of this diatom were recorded in Slovakia in thermal waters at Piešt'any Spa (HindÁK \& HindÁková 2006), namely in small artificial basins supplied with thermal water situated in the health-resort park. Morphologically similar populations were found in the phytobentos of the gravel-pit lake Zlaté Piesky in Bratislava (HindÁKovÁ \& HindéK 2008). This paper presents the results of further studies of collected material. It is concluded that the populations from Pieštany Spa and from a gravel-pit lake in Bratislava actually represent Achnanthes thermalis var. rumrichorum, not var. thermalis.

\section{Material and methods}

Benthic material was investigated from the gravel-pit lake Zlaté Piesky in Bratislava in February 2008. This reservoir is situated at the NE periphery of Bratislava near the road to Senec and the highway to Trnava (N48 $\left.11^{\prime} 5.12^{\prime \prime} ; \mathrm{E} 17^{\circ} 11^{\prime} 11.75^{\prime \prime}\right)$, is J-shaped, occupies an area of 54 ha and has a maximum depth of $11 \mathrm{~m}$.
Shores are irregularly shaped and its bottom consists of an uneven layer of sand and gravel, sporadically covered by sludgy sediments. A small arboreous island is situated in the centre. After the extraction of gravel and sand from alluvial deposits of the Danube river had finished, this man-made lake was filled up with ground water, neutral to slightly alkaline, and started to be used for recreational purposes and sport activities which changed its oligotrophic character to mesotrophic.

In the health-resort park at Pieštany Spa, W Slovakia there are three interconnected artificial basins (N48 $35^{\circ} 15.16^{\prime \prime} ; \mathrm{E} 17^{\circ} 50^{\circ} 35.05^{\circ}$ ) supplied with thermal waters. They are approximately of circular shape, $5-8 \mathrm{~m}$ in diameter, with a concrete bottom and filled by water from the Traian well with a temperature of $67^{\circ} \mathrm{C}$ dropping to $25-38^{\circ} \mathrm{C}$ in summer and $15-28^{\circ} \mathrm{C}$ in winter. The basins are used for growing of decorative water lilies and ornamental fish.

Material was collected from the places overgrown by filamentous algae and water plants. All samples were first examined live, then prepared and treated with hydrogen peroxide by standard techniques (Krammer \& Lange-Bertalot 1986) for LM (permanent slides, mounting medium Pleurax) and EM observations. Permanent slides were examined using a Leitz Diaplan light microscope equipped with a Canon S50 camera. SEM observations were made on cleaned material coated by gold with a Philips 515 microscope operating $30 \mathrm{KV}$ at the Botanic Garden and Botanical Museum Berlin-Dahlem, Germany. The material studied has been deposited at the Institute of Botany, Slovak Academy of Sciences, Bratislava. 


\section{Results}

\section{Morphology}

Cells were solitary (Figs 1, 3) or in pairs (Figs $2,4)$, attached to the substrate by a mucilage stalk (Figs 1-4) secreted from the end of raphe valve (Figs 1,2). Valves in valve view were linear lanceolate (Figs 5-9, 15-20), in the middle appearing swollen (Figs 5, 6, 9, 15, 18), with broadly subrostrate ends, 9-18.5 $\mu \mathrm{m}$ long and 3.3-4 $\mu \mathrm{m}$ wide, markedly curved in girdle view (Figs 10-14, 21, 22), 2.3 to $3.5 \mu \mathrm{m}$ and resembling a „bicorne“ („Napoleonic hat", Figs 11, 14, 22). There was a single plate-like chloroplast (Figs 1,2), and two larger oil droplets. The raphe valve was concave (Figs 10, 15-18, 22), with a variable lanceolate axial area opening into a wide central area, sometimes asymmetrically enlarged to the valve margin (Figs 6,15). The raphe was filiform, straight to slightly curved, central raphe endings were drop-like externally (Figs 15, 16), internally central pores turning to opposite sides of the valve (Figs 17, 18). Terminal fissures were sharply curved around the final valve face stria to the same side externally (Figs 15, 16), internally ended in the helictoglossae (Figs 17, 18).

The raphe-less valve was convex, with a lanceolate, mostly more extended axial area than the raphe valve, axial area was markedly depressed (Figs 19, 21), therefore focussing on two layers of the frustule in LM is needed (Figs 13, 14), the central area was characteristically unilaterally enlarged reaching the valve margin (Figs 8, 9, 19, 20). Striae varied from slightly radiate to parallel, relatively short, uniseriate in the middle of the valve, biseriate towards the ends (Figs 15, 16, 19) and arranged densely, 20-29 in $10 \mu \mathrm{m}$. Striae in the middle of the valve were interrupted on one side on both valves, but the raphe-less valve was marked here by a horseshoe-shaped depression (Fig. 20) appearing in LM as a shadow (Figs 8, 9). The areolae were simple, dot- to dash-like, at the ends at Quincunx-position, internally closed by hymenes (Figs 17, 18, 20), in addition each row of areolae laid in a trough-like depression; valve mantle had no areolae (Figs 21, 22), girdle bands were without pores (Fig. 22).

As Achnanthes thermalis var. rumrichorum was always observed in small numbers and accompanied by the dominant and in some respects similar Achnanthidium minutissimum, this diatom could easily be overlooked or mixed up in the living material. But thanks to its characteristic girdle view (,bicorne“/,Napoleonic hat") its presence in the benthic diatom community could readily be determined.

\section{Distribution}

In material collected by U. and M. RUMRICH from the Quitobaquito creek in Arizona (USA), a taxon with similar characters as the type variety was identified and subsequently classified as Achnanthes thermalis var. rumrichorum LANGEBertalot (Lange-Bertalot \& Krammer 1989). In this new variety it was surprising that instead of mineral waters it occurred in an oligotrophic stream with low electrolyte content.

Research of diatoms from high altitude aquatic environments of Catamarca Province, Argentina (Maidana \& Seeligmann 2006), especially high elevation wetlands, resulted in a first record of Achnanthes thermalis var. rumrichorum also for that country and expanded the knowledge about the distribution of this taxon outside the USA.

In Slovakia Achnanthes thermalis var. rumrichorum has been observed in the two mentioned localities: the gravel-pit lake Zlaté Piesky in Bratislava (identified incorrectly as Achnanthes thermalis var. thermalis in HINDÁKOVÁ \& HINDÁK 2008) and in artificial thermal basins in the health-resort park of Piešt'any Spa (identified incorrectly as Achnanthes thermalis var. thermalis in HindÁK \& HINDÁKOvÁ 2006) where it formed small populations in both localities.

\section{Discussion}

Achnanthes thermalis was described by RABENHORST as Achnanthidium thermale in 1864 from a thermal spring in Bad Cannstatt near Stuttgart, Germany. As numerous thermal springs are found in Europe, one would expected more

Figs 1-14. Achnathes thermalis var. rumrichorum LANGEBertalot. LM view of populations from the gravel-pit lake Zlaté Piesky, Bratislava: (1-4) living material, cells attached to the substrate by a mucilaginous stalk (arrow); (5-14) frustules from permanent slide, (5-7) characteristic valve outline of the raphe valve, (8-9) raphe-less valve with horseshoe-shaped mark (arrow) placed on unilaterally enlarged central area, (10-14) girdle view, (10) raphe-valve marked by arrow; (13-14) two focus levels of frustule, characteristically in the form of a „bicorne“ („Napoleonic hat"). Scale bar $10 \mu \mathrm{m}$. 


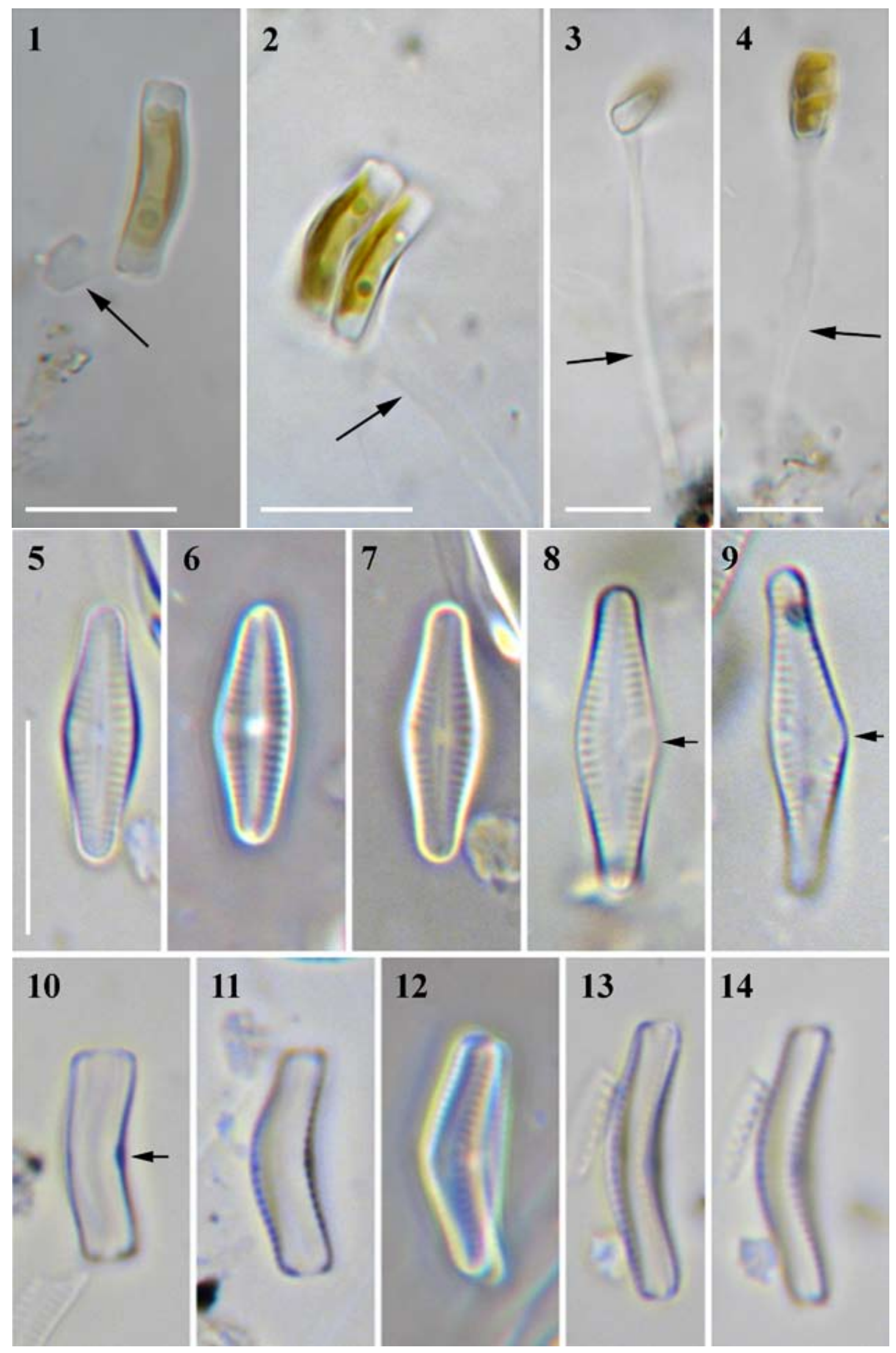



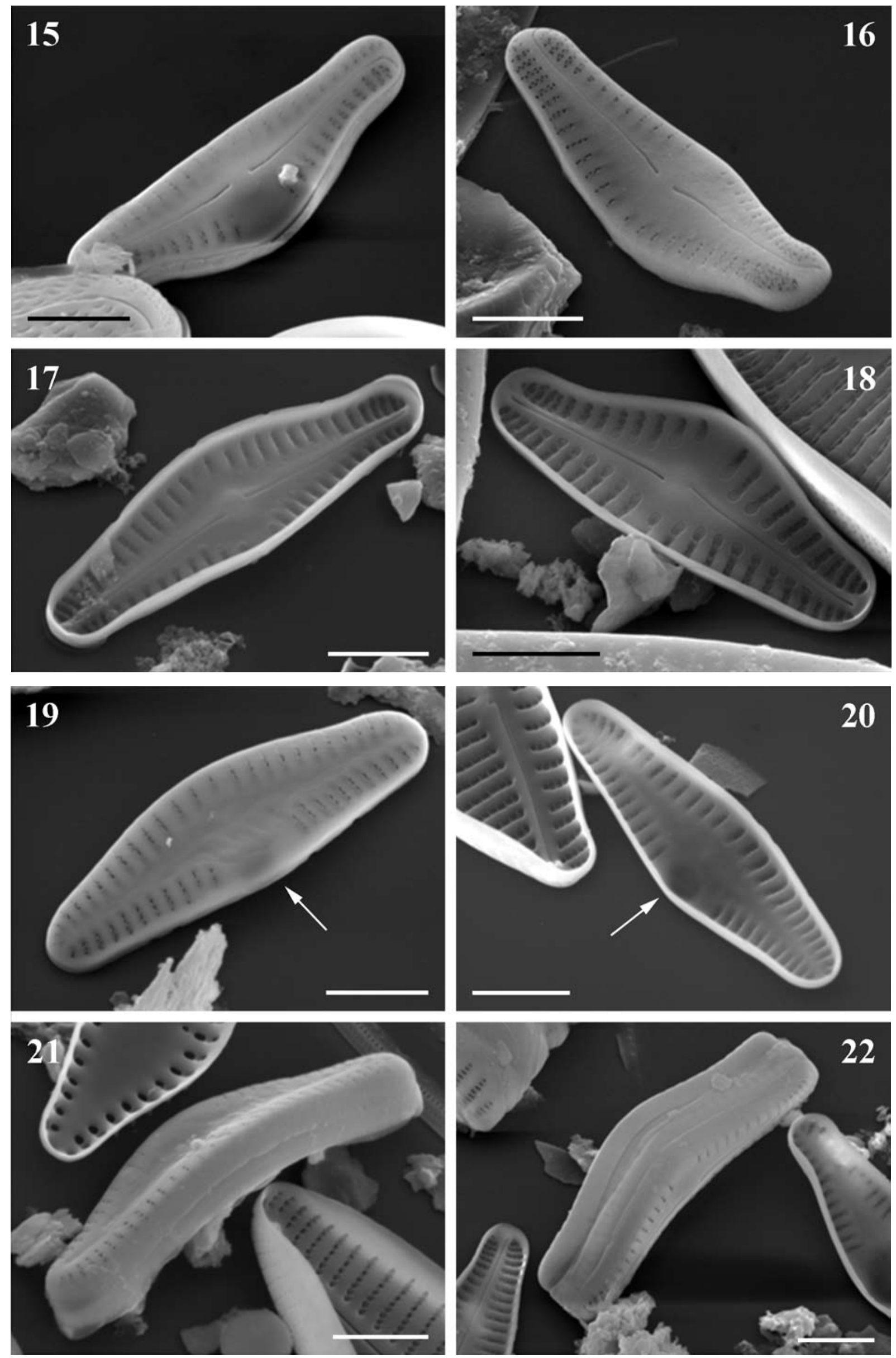
records from other localities. However, this taxon was neglected for many years whereas in the mean time similar new taxa were described from mineral springs. According to Lange-Bertalot \& Krammer (1989), the fact that Achnanthes thermalis remained unreported for a long time was due to the lack of illustrations.

Records of the occurrence of Achnanthes thermalis in Slovakia (as Achnanthes gibberula Grunow and $A$. grimmei KRASSKE, which according to KRAMMER \& LANGE-BERTALOT (1991) are synonyms) concern thermal waters (Bílý 1934) as well as other sites: the river Hnilec, E Slovakia (Bílý et al. 1952) and the water reservoir at Dedinky, E Slovakia (UhERKovich 1967).

Our investigations of thermal waters from Pieštany Spa confirmed that Achnanthes thermalis inhabits artificial basins overgrown with water plants fed by thermal water from the Traian well (HindÁK \& HindÁKovÁ 2006). As populations similar to those from Pieštany Spa were also found in the gravel-pit lake Zlaté Piesky in Bratislava (HindÁKOvÁ \& HindÁK 2008), we decided to reinvestigate our material from both localities.

Populations with evidently smaller valve dimensions and shorter striae densely arranged in the marginal part of the valve face, as well as a modest depression (appearing as a shadow or patch in LM) on the raphe-less valve fully match the definition of Achnanthes thermalis var. rumrichorum (LANGE-BERTALOT \& KRAMMER 1989). The studied material both from Pieštany Spa as well from the gravel-pit lake Zlaté Piesky in Bratislava does not represent Achnanthes thermalis var. thermalis as published by HINDÁK \& HindáKovÁ (2006) and HindÁKovÁ \& HindáK (2008), but var. rumrichorum, thus these are

Figs 15-22. Achnathes thermalis var. rumrichorum LANGEBERTALOT. SEM view of populations from the gravel-pit lake Zlaté Piesky, Bratislava: (15-16) external view of concave raphe-valve with short uniseriate to biseriate striae at Quincunx-position, and central area enlarged to one margin of the valve; terminal fissures sharply curved around the final valve face stria to the same side; (17-18) internal view of raphe-valve, central pores of raphe turned to opposite sides of the valve, areolae closed by hymenes; (19) external view of convex raphe-less valve with ,shadow" (arrow) located at one side, which appears internally (Fig. 20) as a small depression (arrow); (21-22) frustule in girdle view, valve with axial area markedly depressed (Fig. 21), valve mantle and girdle bands without structure. Scale bar $3 \mu \mathrm{m}$. the first records of this variety in the territory of Slovakia. Hence it would be interesting to reinvestigate material both from Piešt'any and Hnilec as studied by BílÝ (BílÝ 1934, BílÝ et al. 1952) to find out which variety of Achnanthes thermalis was really growing in these biotopes.

$\mathrm{Up}$ to now, Achnanthes thermalis var. rumrichorum is still retained in the genus Achnanthes sesu lato. When considering the value of some important characteristic features in this group of diatoms, we can use a feature referred to as a horseshoe-shaped mark (,,hufeisenförmiger Fleck“ or just „Fleck“ in LANGe-Bertalot \& KRAMMER 1989), which is a small depression on one side of the central part of the raphe-less valve. The horseshoe-shaped mark (or hoof-mark) was long regarded as one of the most characteristic features of Achnanthes lanceolata, a taxon that was recently transferred to Lemnicola (Round \& BAsson 1997). GeitLer (1977) observed living populations of Achnanthes lanceolata and considered the relation between valve structure, in particular the horseshoe-shaped structure (,hufeisenförmiger Fleck"), and the cell content with respect to the heteropolar transapical axis. The importance of studies such as GeITLER's is that they improve our understanding of the whole life cycle of diatoms by considering the valve structures as well as the cell's mode of attachment to the substrate.

However, Achnanthes thermalis var. rumrichorum does not have a striking welldeveloped horseshoe-shaped structure, just a small depression appearing as a shadow in LM. A search for species possessing a depression resembling the one in Achnanthes thermalis resulted in two taxa in the identification key of Achnanthes in the fourth volume of the Süßwasserflora von Mitteleuropa (Krammer \& LANGe-Bertalot 1991). These are Achnanthes laevis var. diluviana and A. lauenburgiana members of the H-group and F-group, respectively. After the latest taxonomic changes they are currently placed in the genera Eucocconeis Cleve (as E. diluviana, see LangeBertalot \& Genkal 1999) and Psammothidium BukhtiYarova et Round (as P. lauenburgianum, see BukHtiYARova \& Round 1996). These diverse taxonomic placements appear to suggest that the horseshoe-shaped depression as a structure has limited taxonomic significance.

Achnanthes thermalis var. rumrichorum shares a number of valve structure characteristics with Achnanthidium KütZING and Planothidium 
Round et Bukhtiyarova (cf. Round \& BukhtiYAROVA 1996). However, it cannot be regarded as a definite representative of either genus. The principal differences between Achnanthes thermalis var. rumrichorum and Achnanthidium species are the shape of valve, character of raphe (central and terminal raphe slits), form of axial and central areas, number of series of areolae (uniseriate vs uniseriate to biseriate striae), structure along the valve mantle (presence vs absence of mantle areolae) plus lateral structure - a horseshoe-shaped depression (strictly missing vs almost present). Achnanthes thermalis var. rumrichorum differs from the Planothidium species by the valve outline, angle of curvature of valves, mucilage stalks vs mucilage pads, form of axial and central area and character of raphe. Similarly as in other groups of diatoms, the proper description and classification also of these genera have not yet been resolved satisfactorily and many questions remain unanswered.

\section{Acknowledgements}

The author wishes to thank R. Jahn (Botanic Garden and Botanic Museum Berlin, Germany) for making available scanning electron microscope facilities at this institution, and H.J. Sluiman (Royal Botanic Garden Edinburgh, U.K.) for the English correction. The study was supported in part by the Grant Agency for Science VEGA, Bratislava, project No 2/7069/27, the Science and Technology Assistance Agency, Bratislava, Project 0566/07 and by the EU project Synthesys DE-TAF4677.

\section{References}

Bílý, J. (1934): Píšt'anské rozsivky (Additamentum ad floram Bacillariearum in thermis Píšt'any crescentium.). - Práce Mor. př́rodov. Společ., Brno, 9/1: 1-17.

Bílý, J., HanušKa, L. \& Winkler, O. (1952): Hydrobiológia Hnilca a Hornádu. - 189 pp., Nakladatel'stvo SAV a Umení, Bratislava.

Bukhtiyarova, L. \& Round, F.E. (1996): Revision of the genus Achnanthes sensu lato. Psammothidium, a new genus based on $A$. marginulatum.Diatom Research 11: 1-30.

Geitler, L. (1977): Entwicklungsgeschichtliche Eigentümlichkeiten einiger Achnanthes-Arten (Diatomeae).- Pl. Syst. Evol. 126: 377-392.

Hindák, F. \& HindÁKovÁ, A. (2006): Cyanobaktérie a riasy termálnych vôd $\mathrm{v}$ Piešt’anoch (záp. Slovensko) [Cyanobacteria and algae of thermal waters at the Piešt'any Spa (Western Slovakia) ].-
Bull. Slov. Bot. Spoločn. 28: 21-30.

HindÁková, A. \& HindÁK, F. (2008): Cyanobaktérie a riasy štrkoviskového jazera Zlaté piesky $\mathrm{v}$ Bratislave [Cyanobacteria and algae of the gravel pit lake Zlaté Piesky in Bratislava].Bull. Slov. Bot. Spoločn. 30: 21-27.

Krammer, K. \& Lange-Bertalot, H. (1986): Bacillariophyceae 1. Teil: Naviculaceae.- In: Ettl, H., Gärtner, G., Gerloff, J., HeyniG, H. \& Mollenhauer, D. (Eds): Süßwasserflora von Mitteleuropa 2/1. - 876 pp., Gustav Fisher Verlag, Stuttgart-Jena.

Krammer, K. \& LANGe-Bertalot, H. (1991): Bacillariophyceae 4. Teil: Achnanthaceae. Kritische Ergänzungen zu Navicula (Lineolatae) und Gomphonema.- In: Ettr, H., Gärtner, G., Gerloff, J., Heynig, H. \& Mollenhauer, D. (Eds): Süßwasserflora von Mitteleuropa 2/4.437 pp., Gustav Fisher Verlag, Stuttgart-Jena.

LAnge-Bertalot, H. \& Krammer, K. (1989): Achnanthes eine Monographie der Gattung. Bibliotheca Diatomologica 18: 1-393.

Lange-Bertalot, H. \& Genkal, S.I. (1999): Diatoms from Siberia I. Islands in the Arctic Ocean (Yugorski-Shar Strait). - In: LANGE-Bertalot, H. (Ed.): Iconographia Diatomologica, Ruggell, Liechtenstein, A. R. Gantner Verlag, Vol. 6: $1-271$.

Maidana, N.I. \& Seeligmann, C. (2006): Diatomeas (Bacillariophyceae) de ambientes acuáticos de altura de la Provincia de Catamarca, Argentina II.- Bol. Soc. Argent. Bot. 41: 1-13.

Round, F.E. \& Bukhtiyarova, L. (1996): Four new genera based on Achnanthes (Achnanthidium) together with a re-definition of Achnanthidium.Diatom Research 11: 345-361.

Round, F.E. \& BAsson, P.W. (1997): A new monoraphid diatom genus (Pogoneis) from Bahrain and the transfer of previously described species $A$. hugarica \& A. taeniata to new genera.-Diatom Research 12: 71-81.

Uherkovich, G. (1967): Beiträge zur Kenntnis der Algenvegetation der Umgebung von Dobšiná. II. Über das Phytoplankton der Talsperre von Dedinky. - Zbor. pedag. Fak. Univ. P.J. Šafárika v Prešove, 6: 55-62.

(C) Czech Phycological Society

Received May 1, 2009

Accepted June 1, 2009 